\title{
Analysis on the Inheritance and Practice of Chinese Folk Dance in Colleges and Universities
}

\author{
Yumo $\mathrm{Lu}^{1, *}$ \\ ${ }^{1}$ School of Music and Performing Arts, Mianyang Teachers' College, Mianyang, Sichuan 621000, China \\ *Corresponding author. Email: 1046290187@qq.com
}

\begin{abstract}
Chinese folk dance is an integral part of the cultural context of the Chinese nation, with distinctive national characteristics and profound cultural connotations. Therefore, the teaching of folk dance in colleges and universities should make the inheritance and practice of folk dance on campus continue to improve on the modern road of advancing with the times, pioneering and innovative, and creating brilliant results. It is necessary to do a good job in the inheritance and practice of folk dance in colleges and universities. This article discusses the inheritance and practice of folk dance in colleges and universities, and contributes to the promotion and inheritance of traditional folk art.
\end{abstract}

Keywords: Colleges and universities, Folk dance, Campus inheritance, National culture.

\section{INTRODUCTION}

In traditional national culture, national folk dance is an important part, and the inheritance and development of national folk dance directly affects the inheritance and development of traditional culture. In the teaching of dance specialty in colleges and universities, folk dance is an important course of teaching, and its inheritance and development is one of the important subjects of dance specialty teaching. [1] As a symbol of national culture, Chinese folk dance plays a very important role in the inheritance of culture and art. Through folk dances, people can see the social, economic, political, cultural, and spiritual state of the Chinese nation in its origin and development process, as well as the national aesthetic consciousness, customs, and ecological life. It can be regarded as a vast social history. From the beginning of the Revolution of 1911, the history of more than 100 years, the development of science and technology, the arrival of commercial civilization, traditional culture and modern culture are in a state of separation and confrontation with each other. Folk dance has gradually declined in the history of nearly 100 years. In modern education college education, how to play the communication function of teaching, cultivate excellent talents, inherit folk dances in teaching practice, promote the development of folk dances to be standardized, systematic and stable, promote continuous innovation in the inheritance and development of folk dances, and integrate with modern civilization, has become the main task of college education.

\section{THE INFILTRATION STATUS OF FOLK DANCE IN DANCE EDUCATION IN COLLEGES AND UNIVERSITIES}

\subsection{Current Status of Curriculum Development}

In contemporary times, dance education is advancing with the times to cater to modern educational thoughts, from a weight-focused creation to a qualitative leap. In such an educational environment, there is always a contradiction between the rich educational resources of folk dance and the lack of teaching literacy of folk dance in colleges and universities, and the educational resources of folk dance cannot be integrated into the field of folk dance teaching in colleges and universities in time.

Because exam-oriented education has long been entrenched in the field of college education, colleges and universities have not paid enough attention to folk dance. The schools do not invest 
enough in folk dance teaching resources and neglect the development and utilization of curriculum resources, resulting in an embarrassing situation that the development of curriculum resources is difficult and the success rate of curriculum resources is low. Secondly, the education ignores the mutual infiltration and penetration between disciplines. It is difficult to meet the students' knowledge needs in many aspects and channels, which leads to a narrow field of vision and a single knowledge structure. The artistic elements of folk dance can add new interest to dance education in colleges and universities, reflect the richness and diversity of teaching, improve students' desire to learn, and broaden students' humanistic vision.

\subsection{The Status Quo of Inheritance of Folk Dances}

Under the new situation, with the rapid development of education, the strategic goal of "rejuvenating the country through science and education" has made considerable progress. At the same time as the development of science and technology, traditional folk arts have gradually begun to die out. This is reflected in the fact that the dance majors in colleges and universities have not done enough to inherit folk dance, the folk dance teaching has not formed a systematic teaching system in colleges, education funds and educational resources are insufficient, and folk dance teaching has not been valued from the perspective of education and humanistic care. This situation has caused students to be alienated and unfamiliar with folk dances, unable to fundamentally understand the connotation and artistic essence of folk dances, and seriously lacking of humanistic and professional qualities. The development of folk dance in colleges and universities is difficult. Colleges and universities cannot effectively inherit the art of folk dance, and there are few successors. This kind of teaching situation has seriously affected the dissemination and penetration of national culture. A nation that does not understand its own culture and history cannot see the future of its national culture. Such a nation will not advance in development. As it known to all, the inheritance of folk dance in college dance teaching has become an important topic for promoting national culture, passing on national spirit, and establishing national beliefs. It is conducive to national rejuvenation and cultural return, and has laid the foundation for the construction of national cultural concepts.

\section{THE VALUE OF FOLK DANCE IN THE PROCESS OF INHERITANCE AND PRACTICE IN COLLEGES AND UNIVERSITIES}

\subsection{The Needs of Dance Education Reform}

At the beginning of the 1980s, folk dance entered the field of dance education in colleges and universities, and opened a breakthrough development process in the field of folk dance research, which is of milestone significance to the creation of folk dance art resources and the reform and development of dance education in colleges and universities in China. Catering to the reality of China, as well as the diversified specific national conditions, establishing the concept and awareness of the inheritance of folk dances in China is the core content of the reform of dance education in colleges and universities. The organic combination and mutual penetration of folk dance art and education reform has practical significance for the sustainable development of the inheritance and practice of folk dance in colleges and universities. With the development of social economy and the improvement of science and technology, higher requirements have been put forward for the quality and efficiency of folk dance teaching. Folk dance courses began to cater to the requirements of education reform. Under the advocacy of the concept of quality education in the new curriculum reform, the development of folk dance courses in colleges and universities has become the main strategic position for inheriting China's folk dance. Folk dance has embarked on a new journey in the professional adjustment and reform.

\subsection{The Need to Inherit and Develop Traditional Folk Art}

The important value of colleges and universities should not be ignored for the inheritance and development of local ethnic dance culture. [2] Dance education in colleges and universities is an important position to protect and inherit our local folk dance art. Folk dance art is often produced, inherited and developed under the influence of unique natural climate, geographical environment, social environment and other factors. Dance education in colleges and universities must undertake the important task of inheriting the art of folk dance in China, and use the opportunity of reform in college dance education to apply and develop folk dance art resources so as to promote 
dance education in colleges and universities, enrich the teaching resources of dance education in colleges, and improve the quality of teaching, to enable the effective continuation and development of folk dance art, and bloom a brilliant and dazzling ideal flower on the road of inheritance and development.

\subsection{The Needs of the Development of the Times}

China has a history of 5,000 years. Folk dance is a national heritage left by the people of all ethnic groups in China, and it is a heavy spiritual wealth. For 56 ethnic groups in China, dance is a unique cultural element and artistic inheritance formed during the development of each ethnic group. It has been endless and enduring in the long history. The dance of each nation is a precious heritage in the process of Chinese civilization, forming a flourishing and prosperous artistic situation on the stage of modern folk dance. With the advent of commercial civilization and the advancement of the modernization process, in view of the faults and missing imagination of Chinese national culture, how to restore and inherit traditional folk art in the process of the development of the times, promote the effective integration of modern civilization and traditional folk art, and shape humanistic qualities in the process of mutual integration is a symbol of national art standing firmly in the world and the inheritance of traditional national spirit. The concentrated expression of the humanistic qualities of a nation is to integrate national culture and art, and to be in line with modern civilization. As it known to all that, to develop and innovate in the process of inheritance, promote the art of folk dance to the world, and connect with universal values, so that the world can understand the art of Chinese folk dance and the origin of Chinese national culture and history, can be particularly important.

\section{AN ANALYSIS OF THE INHERITANCE AND PRACTICE OF CHINESE FOLK DANCE IN CAMPUS}

\subsection{Establishing the Concept of National Culture}

National folk dance is the essence of Chinese culture and a concentrated form of carrying cases. Folk dance is a concentrated expression of culture, folk customs, and customs. Therefore, the inheritance of folk dance requires a rich accumulation of ethnic culture. Teachers need to push folk dance to the forefront of the times, so that students can better understand and grasp the spiritual connotation of folk dance. [3] As a modern citizen, it is necessary to have modern ideas and awareness on the one hand, and on the other hand, it is also necessary to have a sense of national culture, a sense of cultural belonging, and a love for the culture of the nation. Only in this way can they learn actively in learning, be willing to innovate, push the art of folk dance to a new research field, continuously enrich its connotation, and carry forward the art of folk dance. As the inheritors and promoters of folk culture, college students should shoulder the historical mission and cultural mission when folk art is declining, inherit and develop folk art, and make vigorous efforts to turn the situation. By mastering the dance art style and cultural connotation, the dance art can be promoted to the stage, which is conducive to the wide spread of dance art and is accepted by the public. Therefore, in the folk dance classroom teaching, high classroom efficiency, permeating national cultural concepts, and realizing the inheritance of national culture are the prerequisites for colleges and universities to inherit and practice the sustainable development strategy of folk dance lessons. At the same time, inheriting national culture and making folk dance art go international is a powerful way to realize the dream of a powerful country. Therefore, folk dance teaching in colleges and universities should pay attention to the infiltration of national culture and take the initiative to teach folk dance culture. This is to pave the way for the comprehensive implementation of quality education practice. Under the new situation, dance teachers must change from the traditional test-oriented education concepts, pioneer and innovate, take the initiative to cultivate students' quality education and comprehensive ability, so that students can enhance humanistic quality, and enhance national cultural pride and self-confidence under the nourishment and influence of national cultural atmosphere, to carry forward the art of folk dance, enabling students to move on to a path of all-round development. Therefore, in folk dance teaching, students should not only master dance movements, but also infiltrate dance national cultural knowledge, such as the origin of dance, cultural concepts in the development process, national customs, philosophical concepts, and humanistic knowledge. Only when the two permeate each other can the combination of folk dance form and god be truly 
realized, so that the human soul and body can develop in a healthy and harmonious manner.

\subsection{Developing Appropriate Folk Dance Teaching Materials}

The national dance teaching course is one of the professional courses of undergraduate dance education in our country. It plays an important role in the cultivation of students' artistic accomplishment and national consciousness. [4] The introduction of folk dance into colleges and universities in China is relatively short, the development model is not yet mature, and there are many types of dance courses. Therefore, the choice of suitable teaching materials can cater to the needs of students and stimulate students' interest in learning folk dance. In the teaching process, teachers should focus on dance teaching materials suitable for the development of students, carry out teaching innovations, improve students' learning efficiency, and improve students' folk dance learning career. In the selection of teaching materials, teachers should be compatible with and promote each other with folk dance, so that while learning dance skills, students systematically study the cultural forms, historical features, development forms, and art forms of dance, which lays the foundation for the development of students' art. For example, some colleges and universities in Northwest China regard Dunhuang dance as an integral part of the teaching content, and personally assist in the practice, and choreograph a lot of dance works. This is inseparable from the systematic study and mastery of humanistic knowledge. Only by fully understanding the comprehensive knowledge system of folk dance, can students be based on the field of folk dance, continuously improve in practice, and choreograph better works. Therefore, the choice of teaching materials determines the direction and development of folk dance, and it has a central role and position in the inheritance and practice of folk dance on campus. Reasonable selection and application of teaching materials are the prerequisite for the success of dance teaching, which is the convergence and condensation of outstanding scientific research results. The infiltration of folk dance art nutrients in teaching materials is the primary factor for the innovation and success of dance teaching in colleges and universities. In the process of innovation in teaching concepts, the compilation of college dance teaching materials must be implemented in practice, and the dance art elements with ethnic regional characteristics must be integrated into the teaching material system to enrich the content of teaching and infiltrate the ethnic cultural elements, so that folk dances are like spring breeze and rain, moistening things silently, deeply rooted in the hearts of the people, and promoting the development of dance teaching in colleges and universities.

\subsection{Improving Teaching Methods}

Classroom teaching of folk dance in colleges and universities is not only to enable students to learn basic dance skills and basic dance knowledge, but to inherit and carry forward folk culture. Therefore, improving teaching methods and carrying out teaching innovations have become an important development track of folk dance teaching in colleges and universities in the new era. In the construction of teaching methods, it is necessary to update teaching concepts, enrich teaching methods, combine internal and external teaching, and integrate performance, learning and research. Teachers should bring folk dance into the classroom and enrich the cultural foundation of folk dance. For example, in addition to traditional oral teaching methods, autonomous teaching methods should be popularized in folk dance teaching in colleges and universities, using the form of imitation training to enhance students' ability to imitate and shape students' keen sense of things. There will be a need to let students imitate the rhythm of folk dance, so that students can master the basic rhythm and style in a relatively short time. In order to promote the stage of folk dance, folk artists can be invited to come into the classroom, impart knowledge, and expand students' horizons and cognitive level. It will be of great significance to move towards development in practice, infiltrate traditional cultural concepts and qualities in development, and establish an ideological basis for communication and exchange with folk art.

\subsection{Optimizing the Educational Environment}

For the folk dance classrooms in colleges and universities, there will be a must to optimize the educational environment, create a free and open teaching environment, guide students to deeply explore the value orientation and cultural connotation of folk dance, provide superior teaching equipment, and make contributions to the creation and development of folk dance teaching. It is also necessary to effectively integrate the educational resources of colleges and universities, 
set up a folk dance art research room, and a dance work research base, and provide professional folk dance equipment to lay the foundation for a complete folk dance teaching system. [5] In the teaching process, the traditional examinationoriented education is transformed to quality education. There will be a lot of benefits to change the traditional teaching method of teaching and indoctrination, give students space for creativity and freedom, hire folk dance art experts to teach folk dance, and integrate the scientific research results of folk dance teaching resources, so as to make actual achievements for the creation of folk dance teaching resources. In terms of teaching evaluation, emphasis should be placed on the development of students' comprehensive abilities. Only in this way can folk dance be effectively inherited.

\section{CONCLUSION}

Folk dance is a concentrated manifestation of folk culture and national spirit. Traditional folk dances in China are declining. Therefore, there is a necessity to find suitable soil for the inheritance of folk dances to ensure that folk dances are passed on in the practice of colleges and universities. In this process, the fork dance will continue to reach the highest point, creating artistic miracles of folk dance elements. Folk dance in colleges and universities plays a very important role in the inheritance of traditional Chinese culture. For folk dance teaching in colleges and universities, it should enhance the connection and communication with the times, promote the inheritance and development of folk dance art, and make the modernization process closely connect with traditional culture. In the teaching practice of folk dance, it enables students to build a complete knowledge system, shape their humanistic feelings, and cultivate inheritors and disseminators of national culture, which are the concentrated requirements for the overall development of education. Folk dance entering the field of college dance teaching plays a very important role in the reform and innovation of college dance education. While enriching college dance teaching, it can effectively promote the inheritance and practice of Chinese folk dance on campus.

\section{AUTHORS' CONTRIBUTIONS}

This paper is independently completed by Yumo Lu.

\section{REFERENCES}

[1] Hou Ming, On the Inheritance and Development of Chinese Folk Dance in the Teaching of Dance Majors in Colleges [J]. Academy, 2017(07): 46-47. (in Chinese)

[2] Ma Lin, Based on the Local Culture, Inheriting the Essence of the Nation Thinking on the Teaching of Qiang Folk Dance [J]. Sichuan Theatre, 2012 (3). (in Chinese)

[3] Ding Xiaohong, My View on the Teaching of National Dance [J]. China Education Innovation Herald, 2013(16): 186. (in Chinese)

[4] Ji Fangfang, Heritage and Development Research of Minority Dance Culture in Yunnan Higher Dance Education [D]. Chinese National Academy of Arts, 2013. (in Chinese)

[5] Meihaayi Kayier, Some Thoughts on Teaching Ethnic Folk Dance in the Context of Quality Education [J]. Journal of Research on Education for Ethnic Minorities, 2010, 21(03): 97-99. (in Chinese)

[6] Wang Mingke. Qiang in the Han and Tibetan Historical Anthropology research of western Sichuan Qiang [MI Beijing: Zhonghua Book Company, 2008.05.(15) Jia Shubing: A Comprehensive review of the development of "New Musicology" in Britain and America since 1980s J. Journal of Central Conservatory of Music 2010102); 115-123. 